\title{
AFRIKAANS AS SANGTAAL*
}

Daar is twee begrippe vervat in die benaming Sangtaal:

Eerstens: Sang, wat een van die onderafdelings vorm van die breë begrip ,musiek", wat op sy beurt weer een van die vertakkings is van die nog breër begrip „kuns”. Aan definisies van kuns en meer spesifiek van musiek is daar geen gebrek nie. Laat ons vir die huidige volstaan met die volgende: Musiek is die sinvolle rangskikking van musikale klanke in 'n sinvolle ritmiese verband. Sang, as een van die middele waarmee musiek gemaak word, maak gebruik van die menslike stem wat daartoe in staat is om verskillende toonhoogtes voort te bring in 'n vinniger of stadiger opeenvolging met mekaar. Die menslike stem kan slegs een toonhoogte op 'n gegewe moment voortbring, en die derde groot element van musiek nl. harmonie (die ander twee is melodie en ritme en is implisiet in die bogenoemde definisie) kan alleen dán na vore kom wanneer een stem in kombinasie met een of meer ander stemme of instrumente aan. gewend word.

Die tweede begrip in die benaming Sangtaal is Taal wat ook van klanke, maar van 'n ander orde, gebruik maak om deur middel van die sinvolle rangskikking van woorde, wat op hul beurt die uiterlike manifestasie van begrippe is, uitdrukking te gee aan menslike idees en gevoelens.

En nou kry ons die samevoeging van sang en taal wat deur die hele geskiedenis van die mensdom een van die sterkste middele in diens van die mens was om uitdrukking te gee aan sy innerlike gevoelens en idees. Van die vroegste tye af is daar gesing - vir en by feitlik alle menslike aktiwiteite - by die jag, die kryg, die arbeid, in huislike kring, by die godsdiensoefening, in vreugde en in leed. En soos 'n bepaalde volk van sy eie taal as sy mees direkte kommunikasie- en uitdrukkingsmiddel gebruik maak, volg dit vanselfsprekend dat wanneer hy sing hy ook sy eie taal as basis vir sy lied sal verkies. Al is hy ook hoe bedrewe in ander tale, bly sy eie taal dié een waarin hy hom die meeste tuis voel. Wie al 'n sanguitvoering van bv. die Spaanse

* Inougurele rede, gelewer op 13 September 1968, by die aanvaarding van 'n professoraat in Musiek aan die P.U. vir C.H.O. deur prof. P. J. de Villiers. 
sangeres Victoria de los Angeles of die ontslape Noorse kunstenares, Kirsten Flagstad bygewoon het, sal saamstem dat, hoe goed hulle hul ook mag kwyt van hul taak in ander tale, daar 'n wonderlike ekstra glans kom in hul vertolking en voordrag van liedere in hul eie taal. Van ons eie vooraanstaande Afrikaanse sangkunstenaars het op my vraag hoe hulle daaroor voel om in Afrikaans te sing, dadelik spontaan hul voorliefde te kenne gegee om in hul eie taal te sing, oor dinge eie aan hul eie omgewing en kultuur. Dit is voorwaar verblydend dat daar op ons konsertverhoë in sanguitvoeringe dikwels oorspronklike Afrikaanse liedere en koorwerke gehoor word. Is dit nie 'n pluimpie vir ons taal en musiek dat 'n Engelstalige koerant in 'n bespreking van 'n onlangse liederuitvoering van een van ons voorste sangeresse die volgende oor die Afrikaanse liedere in haar program te sê gehad het nie?: „... the two South African groups were strongly South African in flavour and created an atmosphere of every-day life in this country". Is dit dan nie waarna ons streef nie, want was die "swains" en "lasses" van die Engeland van hul tyd en die "Schöne Müllerin" of die „Lindenbaum” en die „Heiden Röslein” van Duitsland en Oostenryk van hul tyd dan nie die ,atmosphere of every-day life" in dié onderskeie lande nie?

Hoewel Italiaans, wat as gesproke taal sewe enkelvoudige klinkers bevat en geen diftonge het nie, gewoonlik aanvaar word as die mees singbare taal, word ander tale nie as sangtale gediskwalifiseer omdat hulle bv. wel diftonge bevat nie (Engels bv. bevat 12 enkelvoudige klinkerklanke plus 'n aantal diftonge). Sangers in ander tale moet net harder werk om die gewenste vokale-effek te verkry.

Dit gaan uiteindelik nie daarom of Afrikaans as sangtaal geskik is of nie: enige taal is geskik as sangtaal veral as daar gesing word van dinge wat eie is aan die gebruikers van die taal en die liedere op goeie oorspronklike tekste smaakvol en sinvol gekomponeer is. Ons is dankbaar vir die aantal Afrikaanse liedere wat ons reeds besit, maar ons moet ons komponiste aanmoedig om nog meer Afrikaanse liedere te komponeer, want daar lê nog 'n ryke veld in ons digkuns braak wat in die lied verklank moet word. En dan lê daar nog die opera- en oratoriumgebiede ook - twee gebiede waaraan ons komponiste nog bykans nie geraak het nie. Ek wil graag my waardering teenoor liggame soos die S.A.U.K., die F.A.K. en die A.T.K.V. uit- 
spreek vir wat hulle al in hierdie verband gedoen het en nog doen deur middel van uitsendings, opdragte, prysvrae en publikasies.

Laat ons egter nie chauvinisties word en ons ore sluit vir die groot skat van die wêreldsangliteratuur nie, maar mag ons juis daardeur aangespoor word om steeds hoër hoogtes in ons eie na te streef. Daarom moet elke ernstige sangstudent en koorgroep hul praktiese ondervinding so wyd moontlik maak deur in verskillende tale soveel moontlik van die literatuur te bemeester.

Ek bied u nou, hoewel met huiwering, 'n aantal toonsettings deur myself van Afrikaanse tekste as 'n beskeie bydrae tot die steeds groeiende liggaam van Afrikaanse musiek. Mag $\mathrm{u}$ vind dat die betekenis van die tekste, wat so ' $\mathrm{n}$ verskeidenheid van ons geestesgoedere vertolk, sterker na vore kom deur die ondersteuning wat die musiek daaraan gee, en mag dit boweal in die teken staan van wat die groot Johann Sebastian Bach se leus as musikus was: „Soli Deo Gloria” - Aan God alleen die eer.

Die volgende liedereprogram word as deel van die rede aangebied:

1. Sewe Boerneef-liedjies:

i) Blaas op die pampoenstingel.

ii) Klein Piedeplooi.

iii) Die berggans het ' $n$ veer laat val.

iv) Waarom is die duiwel vir die slypsteen bang?

v) Aandblom is 'n wit blom.

vi) My koekiesveerhen jou verkereveer.

vii) Doer bo teen die rant.

(Vrouekoor).

2. Kleuterland (woorde uit die Kleuterverseboek van D. J. Opperman). (Solostem met klavierbegeleiding).

3. a) In die Hoëveld (Toon van den Heever).

b) Sproeireën (D. J. Opperman).

(Mannekoor).

4. Die Slamaaierwinkel (C. L. Leipoldt). (Gemengde koor).

5. Heilige Nag (Elisabeth Eybers - na die Duits van Auguste Supper). (Vrouekoor)

6. Lof en Smeking. (Klein Psalm-kantate vir onbegeleide ge- 
mengde koor). (Woorde uit die Heilige Skrif):

a) God vaar op met gejuig (Psalm 47).

b) 'n Boetpsalm in groot benoudheid (Psalm $6: 2-5$ ).

c) Loof die Here, die genadige en barmhartige God (Psalm $103: 1-5,20-22$ ).

Uitvoerders: Sarie Lamprecht (alt), Die Cantare Sanggroep van Pretoria. 